\title{
Advisory Opinions: An Alternative Means to Avoid the Development of Legal Conflicts?
}

\author{
Rüdiger Wolfrum*
}

\section{Introduction}

The objective of this brief presentation is to establish whether and under which conditions advisory opinions may play a positive role in avoiding disputes between States. According to a dictum of the International Court of Justice, advisory opinions are not a means "to settle" - at least not directly - disputes between States, but to offer legal advice to the organs or institutions requesting the opinion. ${ }^{1}$

Every legal dispute contains two elements which the parties to that dispute may discuss controversially. First, in most cases parties disagree about the relevant facts. It is true that often more time and effort is spent on the identification of the relevant facts and their interpretation than on the relevant legal issues. Second, parties disagree on which legal rules are relevant and how to interpret them.

It is the hypothesis of this presentation that separating these two elements by means of an advisory opinion, which only deals with the second element of applicability of the relevant rules and their interpretation, may prevent the development of a contentious case. This hypothesis is encouraged by the fact that the international rules concerning the settlement of disputes provide for the possibility of an enquiry into the first element which means the establishment of facts. It is expected that after the factual situation has been established the parties will more easily reach an agreement. ${ }^{2}$ Some national legal procedures also provide for such a possibility.

* Professor of International Law at the University of Heidelberg, former Judge of the International Tribunal for the Law of the Sea.

1 Legality of the Threat or Use of Nuclear Weapons, Advisory Opinion, ICJ Reports 1996, 226, para. 15 .

2 Inquiries belong to the traditional means of settling international disputes. They were already provided in the Hague Convention for the Pacific Settlement of International Disputes of 1899; for further details, see C. Tomuschat, Article 33, in B. Simma et al. (eds.), The Charter of the United Nations: A Commentary, vol. I, $3^{\text {rd }}$ ed., (2012), para. 27. 
Advisory opinions deal, as indicated above, with the other side of a legal controversy namely the relevant law and its interpretation and application. Therefore, the separation of facts and the relevant legal rules is not uncommon under the international rules on dispute settlement. It should also be taken into consideration that such a way of preventing the development of a contentious case may reflect more adequately the legal culture in several regions of the world.

Several standing international courts have the competence to deliver advisory opinions. In that respect they follow the example of the Permanent Court of International Justice which, on the basis of Article 14 of the Covenant of the League of Nations, had such a competence and had developed this mechanism through its jurisprudence. The powers conferred on the International Court of Justice (Article 96 UN Charter; Article 65 ICJ Statute) are similar, and in rendering advisory opinions, the International Court of Justice frequently refers to the jurisprudence of the Permanent Court of International Justice. ${ }^{3}$ Protocol No. 2 to the European Convention for the Protection of Human Rights and Fundamental Freedoms confers power on the European Court of Human Rights to give advisory opinions. No such advisory opinion has been delivered so far; similarly, the American Convention on Human Rights confers a broad competence upon the Inter-American Court of Human Rights to give advisory opinions. Equally, the African Court of Human and People's Rights may give an advisory opinion upon any legal matter relating to the Charter or any other relevant human rights instruments, provided that the subject matter of the opinion is not related to a matter being examined by the Commission. Finally, the Court of Justice of the European Union may be requested to render an advisory opinion on particular issues.

The following presentation will not deal with such competences. It is sufficient to point out that - for different reasons - standing international courts have been empowered to render advisory opinions. In that respect the international scenery is different from national law. Only few national Supreme Courts or Constitutional Courts have the power to give advisory opinions. On the national level it is commonly felt that adjudication and advisory functions exclude each other. Certainly it would be problematic if a court would render an advisory opinion and then be called upon to adjudicate a case concerning the same issue. Such constellation has never happened so far on the international level. One should rest assured that the

3 See K. Oellers-Frahm, Article 96, in B. Simma et al. (eds.), The Charter of the United Nations: A Commentary, vol. II, $3^{\text {rd }}$ ed., (2012), paras. 14-25. 
court in question would be able to handle such a situation in a responsible manner and would not admit such a case.

\section{Advisory Opinions by the International Court of Justice}

According to Article 96 (1) of the UN Charter, the General Assembly and the Security Council may request an advisory opinion from the International Court of Justice. This competence extends to legal questions of any kind and it is de facto not restricted in scope. ${ }^{4}$ On the basis of Article 96 (2) of the UN Charter, other organs of the United Nations and specialized agencies as authorized by the General Assembly may request an advisory opinion on legal questions having arisen within the scope of the activities of that organ or agency. When the Statute of the International Court of Justice was prepared, proposals were made also to authorize individual States to submit requests for advisory opinions. However, these proposals were not accepted. ${ }^{5}$ The main argument against the proposals was that such a possibility would discourage States from submitting cases to the International Court of Justice. ${ }^{6}$ In fact, Article 96 of the UN Charter should be considered in connection with the jurisdiction of the International Court of Justice ratione personae, which only allows States to submit cases to the Court; advisory opinions are the way out for particular international organizations to engage the International Court of Justice on a controversial legal question.

According to Article 65 (1) of the ICJ Statute, the International Court of Justice has discretionary powers as to whether or not to render an advisory opinion. The Court has underlined this character of its obligation although it has never declined to render an advisory opinion for this reason but has emphasized that there must be "compelling reasons" to deny such a request. ${ }^{7}$

4 Ibid.

5 The International Court of Justice has had the authority to review judgments of the ILO Administrative Tribunal as well as the UN Administrative Tribunal by way of an advisory opinion. The provisions on the review system were abolished as unsatisfactory by GA Res. 50/54 of 11 December 1995. Since this authority of the International Court of Justice is rather alien to the system of advisory opinions it will not be dealt with in this context.

6 Oellers-Frahm, supra note 3, para. 12.

7 E.g. Western Sahara, Advisory Opinion, ICJ Reports 1975, 12 at 21, para. 23; comprehensively on the ICJ jurisprudence so far, Legality of the Threat or Use of Nuclear Weapons, Advisory Opinion, supra note 1, para. 14. 
One of the major preconditions for a valid request of an advisory opinion must be that the question raised is of a legal and an abstract nature. The International Court of Justice does not consider it as harmful if the question raised has political implications or such a background as long as the question is couched in legal terms.

The restricted role that the International Court of Justice may play in respect of advisory opinions has been criticized. In consequence of resolution 2723 of the General Assembly of 15 December 1970, some suggestions have been made by States concerning the role of the International Court of Justice. ${ }^{8}$ Some governments have put forward suggestions to strengthen the advisory authority of the International Court of Justice by entrusting it to render advisory opinions upon the initiative of regional organizations and individual States. It was also suggested that arbitral tribunals or international tribunals established under particular treaties might be enabled to consult with the International Court of Justice by these means and that national courts faced with a question of public international law should have the right (or even might be obliged) to use the advisory opinion procedure in order to obtain a ruling on a point of international law arising in a current case before them. This proposal was made to fence in any fragmentation which may have originated from the rulings of specialized international courts or national courts. It was further suggested so as to reduce the difficulties arising in cases where a request for an advisory opinion was related to a pending, or at least potentially pending, dispute by empowering the International Court of Justice to decline an advisory opinion unless the parties to the dispute agreed in advance to accept it as binding. Finally, the suggestion that has regularly been put forward was that the Secretary-General of the United Nations should be authorized to request advisory opinions on his own responsibility. ${ }^{9}$ None of these are suggestions that were discussed in depth and there seems to be no possibility that any might be implemented.

These elements briefly sketched out above were of relevance when the issue of advisory opinions was to be considered under the dispute settlement regime under the UN Convention on the Law of the Sea.

8 See United Nations General Assembly Report: Report of the Secretary-General: Review of the Role of the International Court of Justice, UN doc. A/8382, 15 September 1971, paras. 263-305.

9 H. Thirlway, Advisory Opinions, in R. Wolfrum (ed.), MPEPIL, (2012), 97, 105. 


\section{Advisory Opinions in the Context of the Dispute Settlement Regime under the UN Convention on the Law of the Sea}

According to Article 191 of the Convention, the Seabed Disputes Chamber ${ }^{10}$ shall give advisory opinions at the request of the Assembly of the International Seabed Authority or the Council of the International Seabed Authority on legal questions arising within the scope of their activities. It is evident that this provision is very much tailored along the lines of Article 96 of the UN Charter; however, there are several differences to be noted. According to the terminology of Article 191 of the Convention, the Seabed Disputes Chamber is under an obligation to render the advisory opinion requested. Nevertheless, in the first and only Advisory Opinion of the Seabed Disputes Chamber, it was considered whether the Chamber had discretionary powers to deny such a request. ${ }^{11}$ The competences of the Assembly and the Council of the International Seabed Authority to request an advisory opinion are not unlimited. The advisory opinions requested shall deal with legal questions only, and only those which fall within the scope of the activities of the organ requesting the advisory opinion.

From the wording of the relevant provisions it is evident that advisory opinions decided by the Seabed Disputes Chamber serve the same purpose as those which may be requested by organs of the United Nations or specialized agencies. They are meant to solve disputes between organs but, more prominently, they are meant to guarantee that the organs concerned, in this case the Assembly and the Council of the International Seabed Authority, are carrying out their functions to act within the framework of the Convention and its supplementary rules. The purpose of such advisory opinions is upholding the rule of law. Apart from that, such advisory opinions can indirectly avoid international disputes between the International Seabed Authority and States as well as between the International Seabed Authority and entities engaged in deep seabed activities.

ITLOS may also give an advisory opinion on a legal question on the basis of its Rules "if an international agreement related to the purposes of the Convention" specifically provides for its submission to ITLOS, and the re-

10 The Seabed Disputes Chamber is part of ITLOS composed of 11 of the judges of the latter elected by the full Tribunal. Judgments, Orders or Advisory Opinions of the Seabed Disputes Chamber are considered as those of the full Tribunal.

11 Responsibilities and obligations of States with respect to activities in the Area, Advisory Opinion, 1 February 2011, ITLOS Reports 2011, 10. 
quest is transmitted to ITLOS by whichever body is authorized by, or in accordance with, the agreement to make the request to ITLOS. ${ }^{12}$

In its Advisory Opinion ${ }^{13}$ submitted by the Sub-Regional Fisheries Commission, ITLOS has reconfirmed that its Plenary also has an advisory function, which is separate from the advisory competence of the Seabed Disputes Chamber of the Tribunal referred to above. ITLOS, referring to the competences bestowed upon it in Article 21 of its Statute, stated that the words "all matters specifically provided for in any other agreement which confers jurisdiction on the Tribunal" indicated that it had competences besides deciding on contentious cases. In clarifying this position, it emphasized that Article 21 and the agreement in question are interconnected and as such constitute the legal basis of the advisory function of the Tribunal. ${ }^{14}$

According to the broad wording of Article 21 of the ITLOS Statute and Article 138 of the ITLOS Rules, advisory jurisdiction of the Tribunal is not restricted to international organizations. Article 138 of the Rules is clear in this respect. A request for an advisory opinion before the Tribunal has to be transmitted to the Tribunal "by whatever body" is authorized pursuant to an international agreement related to the purposes of the Convention. On this basis, States could consider submitting a request for an advisory opinion to the Tribunal through an international "body" identified in the agreement.

In practical terms, States faced with a particular issue may conclude an international agreement providing for recourse to advisory proceedings before the Tribunal, for instance, where negotiations fail to produce a positive result within a certain time-limit. In accordance with the international agreement, the designated "body" - for example a mixed commission constituted by the agreement - could subsequently decide to request an advisory opinion from the Tribunal on a specific legal question. One may consider whether theoretically the Meeting of States Parties to the Convention might also constitute a "body" authorized to request an advisory opinion if the necessary agreement has been established.

The advisory opinion would be restricted to answering the specific legal question as stated in the request. It may be noted that the Tribunal would not be competent to answer a question which would not be drafted as a

12 Article 138 of the Rules of the Tribunal, International Tribunal for the Law of the Sea (ITLOS Rules).

13 Request for an Advisory Opinion submitted by the Sub-Regional Fisheries Commission, Advisory Opinion, 2 April 2015, ITLOS Reports 2015, 4.

14 Ibid., para 58. 
legal question (or which would address a situation that falls outside the competence of the requesting body). In addition, the Tribunal could not answer a question if the result would be to decide on the merits of a pending dispute. Indeed, as in the practice of the ICJ, it may happen that a legal question submitted to the Tribunal would address some aspects of a dispute or of a "legal question pending" between two or more States. However, the question should be drafted in such a way as to avoid having a direct bearing on the merits of a dispute between States.

In accordance with Article 138, paragraph 3, the Tribunal, in dealing with a request for an advisory opinion, would apply mutatis mutandis the rules applicable to advisory proceedings before the Seabed Disputes Chamber. This means that whenever the request for an advisory opinion relates to a legal question pending between two or more parties, the provisions concerning ad hoc judges (Article 17 ITLOS Statute) would apply. Therefore, if the Tribunal confirms that this is the case, the "parties" concerned could designate a judge ad hoc.

In advisory proceedings, States would be invited to submit written statements on the legal question within a certain time-limit and a hearing would be held if the Tribunal so decides. This element constitutes the most significant advantage of advisory proceedings. In an advisory opinion, the Tribunal could base its advice upon written observations of 22 States and 7 international organizations. This means that the impact which interested or affected States and international organizations may have upon the advice is by far more intensive than States may have on a contentious case.

I should add that advisory proceedings are normally conducted more rapidly than contentious proceedings and that the Tribunal would be guided by any indication in the request regarding the urgent character of the question submitted to it.

As previously indicated, advisory proceedings offer a potential alternative to contentious proceedings and could be an interesting option for those seeking a non-binding opinion on a legal question or an indication as to how a particular dispute may be solved through direct negotiations. To illustrate the useful role that the Tribunal could play in this respect, I would like to give two examples.

As in the advisory opinion referred to already, parties to a fisheries organization may make use of the Tribunal's advisory function if they wish to seek guidance as to how a particular situation should be seen from a legal point of view. Questions may concern the compliance of the conservation and management measures taken by a coastal State with the provisions of the Convention or the legality of its enforcement measures including the penalties imposable under national law or the rights and obligations of 
States fishing in the exclusive economic zones of particular coastal States. States might also ask the Tribunal for legal guidance about contemporary issues such as illegal, unreported, and unregulated (IUU) fishing, including trans-shipment, supply or refuelling of fishing vessels. Likewise, States Parties to a particular fisheries agreement such as the Straddling Fish Stocks Agreement may take advantage of the advisory proceedings before the Tribunal in the event of disagreement about the implementation of the agreement.

The second example concerns delimitation matters. The parties to a delimitation dispute could ask the Tribunal to determine the principles and rules of international law applicable to the situation and undertake thereafter to establish the boundary on that basis. In particular they could inquire about how to treat low tide elevations and request guidance concerning the interpretation of Article 121 of the Convention; in particular what qualifies a high tide maritime feature as an island generating an EEZ and a continental shelf.

A particular advantage of such an approach is that the Tribunal would be forced to decide the questions put to it in general, detached from a particular situation. This is more appropriate than dealing with such an issue in a contentious case between two States. Such a contentious case artificially polarizes the question although it is of interest to a wider community, maybe even the global community. The counterargument thereto, that a decision in a contentious case is only binding upon the parties concerned and therefore no wider community is affected, is not convincing. Certainly, judgments in contentious cases are only binding upon the parties concerned but this only means the dispositive. The reasoning in the judgment, in particular the interpretation of a particular norm, has further reaching consequences. Following judicial decisions will rely, and will have to rely, on previous jurisprudence to avoid fragmentation of international law. The sum of the existing jurisprudence is the corpus for subsequent decisions; although speaking of the "law-making powers of judges" does not cover this phenomenon adequately.

To conclude, advisory proceedings before ITLOS may constitute a viable mechanism to prevent international disputes and thus may, used with caution, supplement the dispute settlement mechanisms established in the Convention. 